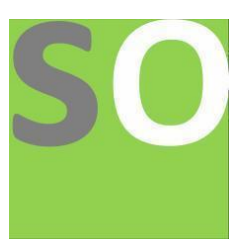

Article title: Morphology and yield performance of edible mushrooms on different substrates

Authors: Tanmay Kotasthane[1]

Affiliations: MJ College[1]

Orcid ids: 0000-0003-2060-1236[1]

Contact e-mail: ktanmay25@yahoo.com

License information: This work has been published open access under Creative Commons Attribution License http://creativecommons.org/licenses/by/4.0/, which permits unrestricted use, distribution, and reproduction in any medium, provided the original work is properly cited. Conditions, terms of use and publishing policy can be found at https://www.scienceopen.com/.

Preprint statement: This article is a preprint and has not been peer-reviewed, under consideration and submitted to ScienceOpen Preprints for open peer review.

Funder: ---

DOI: 10.14293/S2199-1006.1.SOR-.PPUUHCO.v1

Preprint first posted online: 10 June 2021

Keywords: Mushrooms, substrates, yield, morphology 


\title{
Morphology and yield performance of edible mushrooms on different substrates Tanmay Kotasthane
}

Email:ktanmay25@yahoo.com

\begin{abstract}
:
Edible mushrooms were studied for morphology and yield performance.Oyster mushroom,milky mushroom and paddy straw mushroom were studied for spawn run ,pin head formation and fruiting bodies.Sugarcane bagasse,coconut coir, mixture of sorghum and maize stalk, saw dust were used as substrate.Highest yield observed on mixture of sorghum and maize stalk for P.sajor-caju $(800.16 \mathrm{~g})$ followed by P.ostreatus (675.14g).C.indica has good yield on paddy straw (500g).V.volvacea has good yield on $(550.18 \mathrm{~g})$.These mushrooms can be further explored for medicinal properties.
\end{abstract}

Key words: Mushrooms, substrates, yield, morphology

\section{Introduction}

Mushrooms occur in different parts of the world, ranging from arctic to the tropics. While some species are endemic, others exist in areas that are widely separated geographically. However, most of the species show a preference for a certain type of habitat. Some are, found primarily in upland wooded areas; others exist in swamps and still others prefer open areas such as gardens, trees, lawns or pasture e.g Pleurotus spp. Many species particularly the mycorrhizal forms are associated with certain types of vegetations. Mushrooms may also show a preference for a particular substratum within a certain habitat. Basidiocarps of some are typically produced on the soil and are terrestrial forms. Others are saprophytes found on dead leaves (follicolous) or litter e.g Cortinarius melliolens and Tricholoma lobayensis, on wood (lignicolous) e.g Lentinus edodes. Mushrooms are mostly found on wastes such as sawdust, garbages and composting materials. The recent production data revealed that button mushroom production holds the maximum share of about 73 per cent and followed by oyster mushroom with 16 percent (Sharma et al.,2017).The next most common commercial species are shiitake (Lentinus edodes), straw (Volvariella volvacea), oyster (Pleurotus ostreatus), and enoki (Flammulina ostreatus). There are several species of Pleurotus identified in the world and suitable for cultivation, some of them are Pleurotus ostreatus, P. florida P. sajorcaju, P.eryngii (Nadir et al.,2016).Oyster mushroom (Pleurotus spp.) is very easy to cultivate and various agricultural wastes are being used as substrates for its cultivation.Cultivation of edible mushrooms might be the only current process that combines the production of protein-rich food with the reduction of environmental pollution (Sanchez, 2010). Studies have revealed that mushrooms offer a diversity of flavour,texture, and nutrients (Rahi D.K and Malik D, 2016) 


\section{Material Methods}

Spawn of milky mushroom (Calocybe indica) and paddy straw mushroom V.volvacea obtained from Indian Institute of Horticulture(ICAR),Bangalore Oyster mushroom spawn (Pleurotus sajor-caju) was obtained from College of Agriculture pune. Pleurotus ostreatus spawn was obtained online.

In the present investigation yield performance of Pleurotus ostreatus, Pleurotus sajor-caju,V.volvacea and Calocybe indica studied on different substrate. Substrate used is mixture of Maize stalk and sorghum stalk,saw dust,sugarcane bagasse and coconut coir were soaked in water with bavastin, bleaching powder and 5\% formalin overnight. Substrate were kept for sun dry to remove excess water.6X4 polythene bags filled with substrate. Casing is done with (soil + cow dung) for milky mushroom after spawn run.

Collection of mushroom substrate: The substrate for mushroom cultivation (Sorghum stalk ,Coconut coir, Sugarcane stalk, Paddy straw) was collected from the farmers field nearing The substrate after chopping into 3-4 cm length was stored under a covered shade.

\section{Spawning and cropping of mushroom :}

After sterilization, the straw was taken out from water, put in a slanting position to drain out the excess water or cooled in case of hot treatment and then bags were prepared. Polythene bags of $40 \times 60 \mathrm{~cm}$ size were taken, perforated by making random holes in each bag and used to put the spawn and substrates. The bagging was done by layer method by putting 3 per cent of spawn on wet weight basis of the substrate. Each bed contained one kilogram of substrate. After completing spawning the bags were kept in dark room and necessary records were taken periodically. On completion of spawn run the poly bags were removed from the bed, kept in cropping room, watering was done regularly to keep them moist. The mushroom was harvested up to third flushes.

Recording of data: Days for completion of spawn running : Time was recorded in days for the completion of 100 per cent growth of mycelium on each substrate in polythene bags. Days for the appearances of pinhead: The data were recorded in days taken for appearance of mushroom primordial formation in substrates. Maturation of fruiting bodies: Time period was recorded in days from pinheads to maturation of fruiting bodies in all treatments. Yield: The data were recorded for the harvesting of mushroom up to three flushes. The first and respective harvesting was done at maturity and the yield of different flushes of fruiting bodies was noted. 


\section{Result \& Discussion}

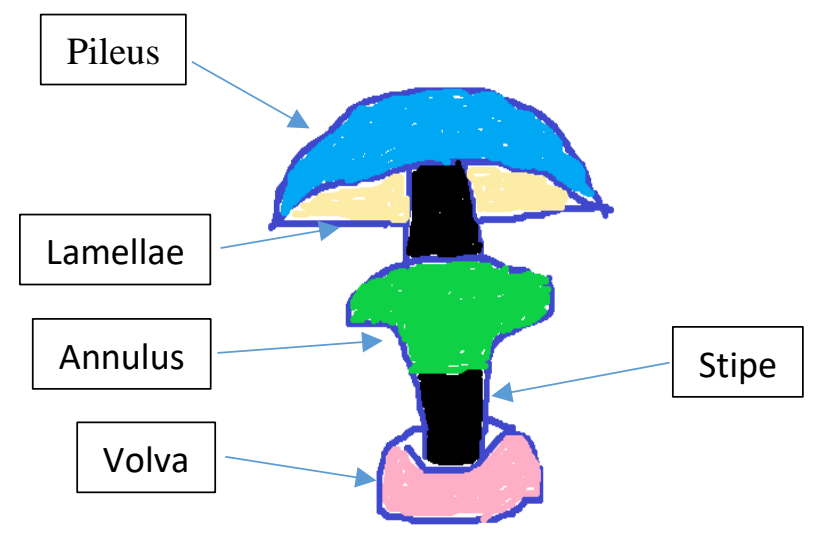

Mushroom Morphology

Table 1

\begin{tabular}{|l|l|l|l|l|l|}
\hline & & $\begin{array}{l}\text { Pleurotus } \\
\text { ostreatus }\end{array}$ & $\begin{array}{l}\text { Pleurotus } \\
\text { sajor caju }\end{array}$ & Calocybe indica & V.Vovacea \\
\hline Habitat & $\begin{array}{l}\text { Wood, leaf } \\
\text { litter,trees }\end{array}$ & $\begin{array}{l}\text { Wood, leaf } \\
\text { litter,trees }\end{array}$ & Grassland & Paddy straw \\
\hline & Volva & Present & Absent & Absent & Present, prominent \\
\hline & Lamellae & Circular & Blade & Equal & Angular \\
\hline & Pileus & Present, white & $\begin{array}{l}\text { Present, Grey } \\
\text { color, large }\end{array}$ & White, Umbrella & Angular \\
\hline & Stipe & $\begin{array}{l}\text { Tappering at } \\
\text { base }\end{array}$ & Small & Present, Bulbous & Thin stalk \\
\hline & Annulus & Present & Absent & Absent & Absent \\
\hline & Odour & Bitter sweet & Farinaceous & Farinaceous & Not distinctive \\
\hline
\end{tabular}

Edible mushroom (oyster, milky mushroom, paddy mushroom) were studied for presence of different parts of mushroom i.e pileus, lamellae, annulus, stipe given in (table1).Pleurotus sajor-caju is large sized mushroom without stipe. Milky mushroom(C.indica) has white cap like pileus with rouded base.Paddy mushroom V.volvacea is pink in color conical shaped, thin stipe with prominent volva.

Along with the methodical characterization of fungal communities in casing soil, a practical analysis is needed to highlight potentials and applications (Murmu et al., 2020).Pleurotus sajor caju,Pleurotus ostreatus,C.indica and V.volvacea studied for spawn running,pinhead formation,fruit body formation and yield.(Park et al.,2014) studied the effect of apple pomace on the growth rate of Pleurotus ostreatus mycelium.Yield performance varied within substrates Pleurotus sajor-caju has highest yield on substrate of maize and sorghum stalk (800.16 g) (Table2).Pleurotus ostreatus shown good yield on paddy straw with (675.14g).C.indica has good yield on paddy straw (500g).Coconut coir is good substrate but has low yield 
as compare to paddy straw and mixture of maize and sorghum stalk (Table 2,3). Saw dust is not recommended for any of these mushroom.Higher yield of quality mushroom depends upon proper maintenance of pure culture as well as purity and quality of the spawn used. Hence, low cost and quality spawn is the basic requirements for mushroom growers (Maurya et al.,2019).

\subsection{Pleurotus sajor caju}

Table 2

\begin{tabular}{|l|l|r|l|l|}
\hline Substrates & $\begin{array}{l}\text { Spawn } \\
\text { running }\end{array}$ & $\begin{array}{l}\text { Pinhead } \\
\text { formation }\end{array}$ & $\begin{array}{l}\text { Fruiting } \\
\text { body } \\
\text { formation }\end{array}$ & Yield (g) \\
\hline Paddy straw & $17-20$ & $21-23$ & $25-27$ & 650.14 \\
\hline Mixture of Maize \& sorghum stalk & $20-23$ & $24-27$ & $27-30$ & 800.16 \\
\hline Saw dust & $20-25$ & $27-28$ & $30-32$ & --- \\
\hline Coconut coir & $20-23$ & $23-25$ & $25-27$ & 500.12 \\
\hline
\end{tabular}

\subsection{Pleurotus ostreatus}

Table 3

\begin{tabular}{|l|r|r|r|l|}
\hline Substrates & $\begin{array}{l}\text { Spawn } \\
\text { running }\end{array}$ & $\begin{array}{l}\text { Pinhead } \\
\text { formation }\end{array}$ & $\begin{array}{l}\text { Fruiting } \\
\text { body } \\
\text { formation }\end{array}$ & Yield (g) \\
\hline Paddy straw & $17-20$ & $21-23$ & $25-27$ & 675.14 \\
\hline Mixture of Maize \& sorghum stalk & $21-22$ & $23-25$ & $25-28$ & 650.12 \\
\hline Saw dust & $20-24$ & $23-25$ & $27-29$ & ---- \\
\hline Coconut coir & $20-21$ & $23-25$ & $25-27$ & 500.16 \\
\hline
\end{tabular}

*Poor spawn run and fruit b-ody formation on saw dust as substrate

\subsection{Calocybe indica}

Table 4

\begin{tabular}{|l|c|c|l|l|}
\hline Substrates & $\begin{array}{l}\text { Spawn } \\
\text { running }\end{array}$ & $\begin{array}{l}\text { Pinhead } \\
\text { formation }\end{array}$ & $\begin{array}{l}\text { Fruiting } \\
\text { body } \\
\text { formation }\end{array}$ & Yield (g) \\
\hline Paddy straw & $23-25$ & $27-29$ & $31-35$ & 500 \\
\hline $\begin{array}{l}\text { Mixture of Maize \& sorghum } \\
\text { stalk }\end{array}$ & $25-27$ & $30-32$ & $33-36$ & 300 \\
\hline Saw dust & $20-25$ & $27-28$ & $30-32$ & --- \\
\hline
\end{tabular}

3.4 V.volvacea

Table 5

\begin{tabular}{|l|c|c|l|l|}
\hline Substrates & $\begin{array}{l}\text { Spawn } \\
\text { running }\end{array}$ & $\begin{array}{l}\text { Pinhead } \\
\text { formation }\end{array}$ & $\begin{array}{l}\text { Fruiting body } \\
\text { formation }\end{array}$ & Yield (g) \\
\hline Paddy straw & $17-20$ & $21-23$ & $25-27$ & 400.15 \\
\hline Mixture of Maize \& sorghum stalk & $20-23$ & $24-27$ & $27-30$ & 550.18 \\
\hline
\end{tabular}


Spawn run

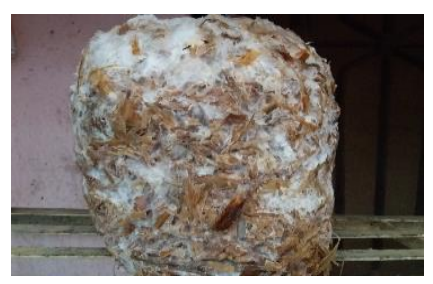

P.ostreatus on Sorghum stalk /Maize stalk Mix
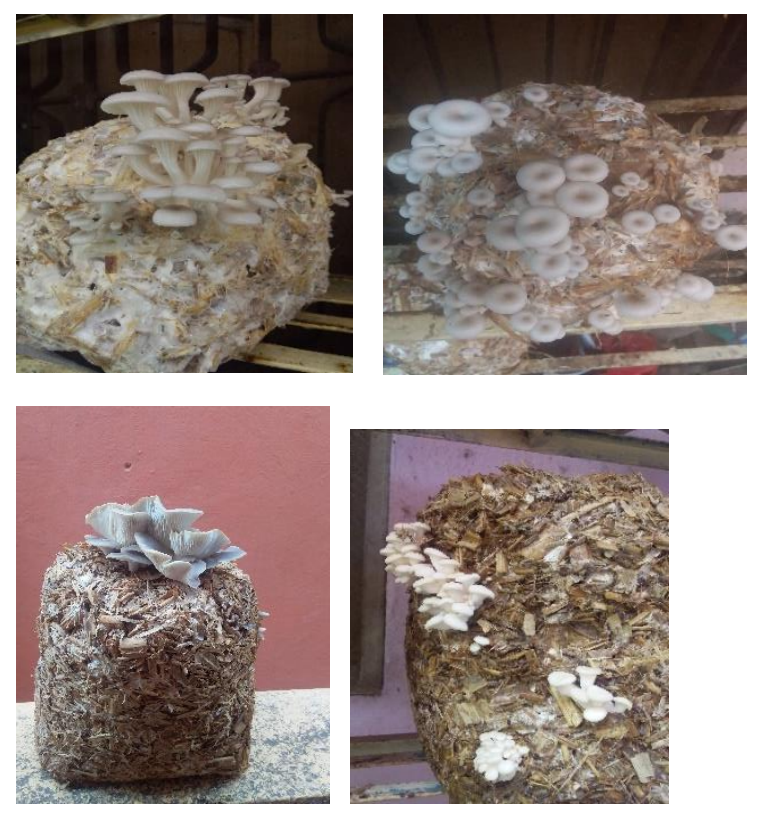

Pin head formation
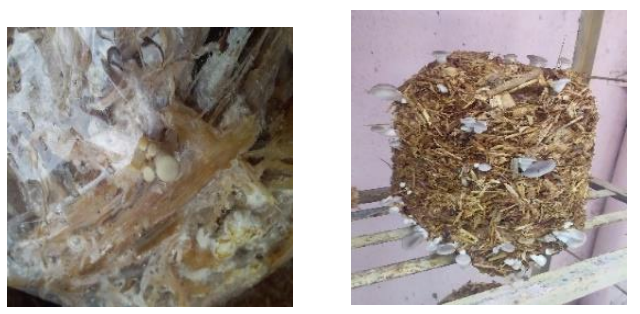

\section{P.ostreatus on Coconut coir}
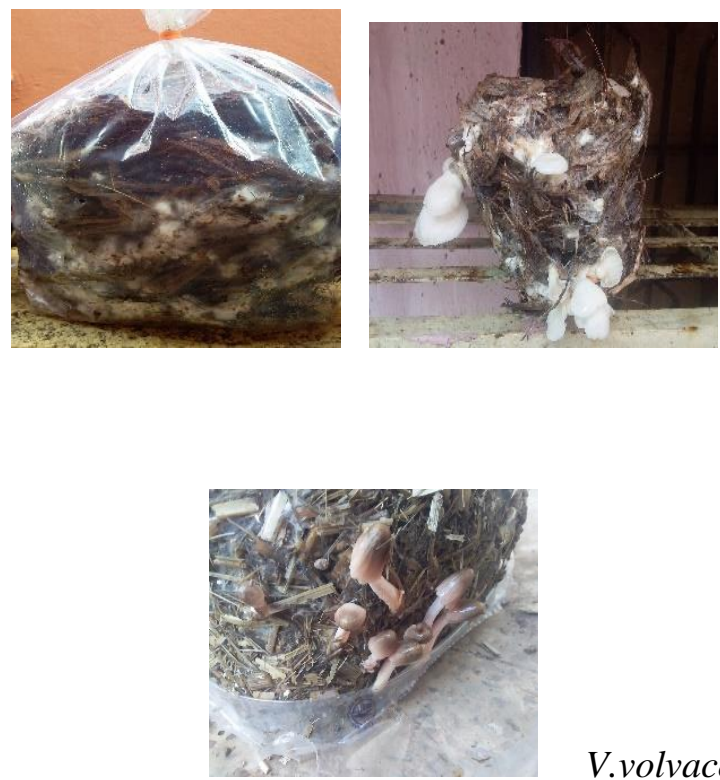

V.volvacea

Pleurotus and C.indica on sugarcane
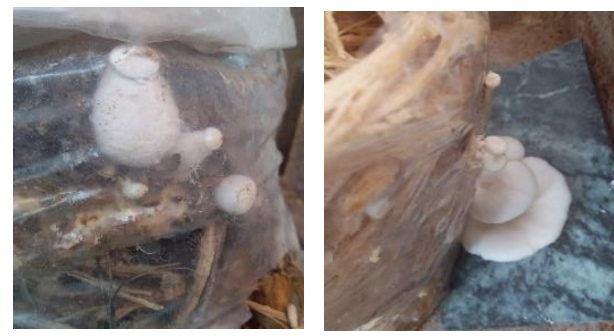


\section{Conclusion}

Oyster mushroom, milky mushroom and paddy straw mushroom are edible and has medicinal properties. These mushroom can be grown on number of substrates available in agricultural field.Oyster mushroom and paddy mushroom is easy to cultivate whereas, milky mushroom require optimum growth conditions and good casing material.Oyster mushroom and paddy straw mushroom can be grown round the year whereas, milky mushroom grown in tropical region from march to october months. These edible mushroom could be explored for medicinal, aromatic and chemical compounds.

Data Availability The data supporting the findings of this study are included in this research article.

Conflicts of Interest The authors declare that there is no conflict of interest regarding the publication of this paper.

\section{References}

Chang ST. 1996 Mushroom research and development - equality and mutual benefit. In: Royse DJ, editor. Mushroom biology and mushroom products. University Park (PA): Pennsylvania State University Nadir HA, Ali AJ and Muhammed GA. 2016. Determination of Yield and Quality of Oyster Mushroom (Pleurotus florida) Using Different Substrates in Halabja, Kurdistan. Plant Production, 7: 787-790.

Maurya, A. K., Murmu, R., John, V. and Simon, S. 2019. Impact of different substrates for spawn production and production of milky mushroom (Calocybe indica). Int. J. Pharma Bio. Sci; 10(3): 5-10. ISSN 0975-6299, DOI: http://dx.doi.org/10.22376/ijpbs.2019.10.3.b5-10

Murmu, R., Maurya, A. K. and John, V. 2020. Mycoflora of certain casing materials used in the production of white button mushroom (Agaricus bisporus (Lange) Imbach). International Journal of Chemical Studies; 8(2): 2863-2868.

Park, C.H., Lim, J., Lee, Y., Lee,B., Kim, S., Lee, J. and Kim, S. 2007. Optimization and morphology for decolorization of reactive black 5 by Funalia trogii. Enzy. Microb. Technol.,40: 1758-1764. https://doi.org/10.1016/j.enzmictec.2006.12.005

Rahi D.K and Malik D 2016,"Diversity of mushrooms and their metabolites of nutraceutical and therapeutic significance,"Journal of Mycology, vol. 2016, 18 pages,

Sanchez, C. 2010. Cultivation of Pleurotus ostreatus and other edible mushrooms. Appl. Microbiol. Biotechnol., 85 : 1321-1337

Sharma VP, Annepu SK, Gautam Y, Singh M,Kamal S 2017.Status of mushroom production in India. Mushroom Research;26(2):111-120. 